is that women already are, as a rule, somewhat inferior in mental power to men, forgetting that they were precisely made inferior by the obstacles thrown for centuries in the way of their advance (some of these specially fixed by legal enactment), and which are sometimes of such a kind as almost to amount to a tax on liberty. It may well be conceivable that the law of inheritance, though it has achieved a vast amount, may not have been able to combat these artificial conditions for producing inferiority with entire success. The above plea of existing inferiority in mental power, therefore, so far from being an argument against female education, ought, when justly viewed, to be regarded as the strongest reason the other way. For if obstruction has produced--in spite of the powerful countervailing influence of the law of inheritance-a certain degree of inferiority: so (conversely) by equally reliable casual sequence encouragement would produce an effect in the opposite direction. Moreover, preciscly on account of the fact that woman is already somewhat handicapped by nature in the race of progress, would there be all the more reason why every encouragement should be given; $\dot{a}$ fortiori, all artificial hindrances in the way of advancement removed. It would be a great mistake if the idea were for one moment entertained that progress can be accomplished by letting matters generally drift under the influence of prevailing custom. If there is one thing more certain than another it is that man can never hope to progress with satisfactory rapidity without having a sharp eye to the conditions necessary for this object, and examining (by the light of reason and knowledge gradually acquired) all his customs, to see if they are desirable or not. To facilitate this end the history of past progress, unfolded in the theory of evolution, may afford some valuable instruction. The increasing appreciation of the value of co-operating with the weak, instead of domineering over them, may be perhaps regarded as one of the most plcasing accompaniments to the advance of science.

S. TOlver PRESTON

THE YANG-TSE, THE YELLOW RIVER, AND THE PEI-HO

$\mathrm{T}$ HESE three rivers form conjointly the great riversystem of China. Although at the present day each of them runs its separate course to the sea, there is good reason to belicve that several centuries since they were united by a number of connecting branches in a manner somewhat resembling the junction of the Ganges and the Brahmapootra in our own time. Such is the inference to be drawn from an ancient Chinese map copied by Alvarez Semedo, a Portuguese Jesuit, and which must be assigned to a time preceding that of the construction of the Grand Canal by Ghenghis Khan in the beginning of the thirteenth century." Linked together as these rivers were in the past, a brief consideration of their present condition will prove that they are labouring towards the same end in our own day. But before proceeding to examine them in their conjoint character, it will be necessary to consider briefly their leading bydrological features.

I. The Yang-tse-the largest and most important of these thrce rivers-has a course of about 3,00o miles, and drains an area which is variously estimated between 750,000 and 550,000 square miles : for my own calculations I will adopt the mean of these two estimates, namely,

${ }^{x}$ The author, Surgeon H. B. Guppy, of H.M.S. IIornet, writing from Yokohama, February 1x, says:- "I forward to you by this mail a paper containing the results of observations I have made during the last two years on the sulject of the Yang-tse and the Pei-ho, together with similar information as regards the Ycllow River. Iooking on these three rivers as in reality one river-system, I have embodied in one paper all the data concernin I can answer for the accuracy of the various estimations, and have employed i can answer for the accuracy of the vari

the usual methods in obtaining them." River," published in the Geographical Magazine for April, 1878 .
650,000 square miles. Its waters, commencing to rise in February and March, reach their highest level in the month of June or July; and here they remain with occasional fluctuations till the end of August or the beginning of September, finally reaching their lowest level towards the close of January.

With regard to the discharge of water of this river, Capt. Blakiston ${ }^{1}$ has estimated the average amount carried past T-chang, which is situated at about 960 miles from the sea, at 500,000 cubic feet per second; he founded this estimate on observations made during the months of April and June. When stationed at Hankow in the winter $1877-78$, a place distant about 600 miles from the sea, I set to work to make a similar estimate of the water carried past that city for the twelve months included between May 1877 and May I878. Having taken a line of soundings across the river and having ascertained the river's breadth ( 1,450 yards, by sextant measurement) at a point below the union of the Han with the main stream, I commenced a series of observations on the rise and fall of the river water and on the force of the current, which, combined with information received from the Customhouse and from other sources, supplied me with the necessary data for my calculation. The results are contained in the following table:-



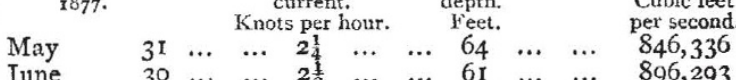

$$
\begin{aligned}
& \begin{array}{llllllllllr}
\text { June } & 30 & \ldots & \ldots & 2 \frac{1}{2} & \ldots & \ldots & 61 & \ldots & \ldots & 896,293 \\
\text { July } & 31 & \ldots & \ldots & 3 & \ldots & \ldots & 58 & \ldots & \ldots & \text { r, 022, } 656
\end{array}
\end{aligned}
$$

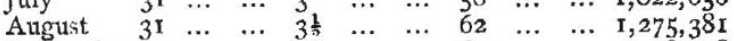

$$
\begin{aligned}
& \begin{array}{lllllllllll}
\text { September } & 30 & \ldots & \ldots & 2 \frac{3}{4} & \ldots & \ldots & 63 & \ldots & \ldots & \text { 1, } 018,248
\end{array}
\end{aligned}
$$

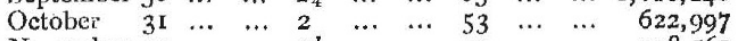

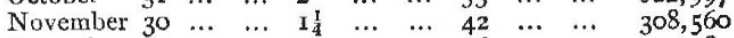

$$
\begin{aligned}
& \begin{array}{lllllllllll}
\text { December } & 31 & \ldots & \ldots & \text { I } & \ldots & \ldots & 36 & \ldots & \ldots & 21 \mathrm{I}, 584
\end{array} \\
& \text { ז878. } \\
& \text { January } \\
& \text { February } \\
& \text { March } \\
& \begin{array}{lllllll}
3 \mathbf{I} & \cdots & \cdots & \frac{4}{5} & \cdots & \cdots & 30
\end{array} \\
& \text { 30 } \quad \cdots \quad \cdots \quad 141,085 \\
& \text { April } \\
& 31 . \\
& \text {... } \\
& \ldots . \\
& 30 \\
& \cdots \\
& \text { … } \quad \cdots \quad 45 \\
& \text { … } 5 \\
& \begin{array}{l}
39 \\
45 \\
57
\end{array}
\end{aligned}
$$

We may therefore place the average water-discharge for the year at Hankow at 650,000 cubic feet per second. Now, estimating the area of drainage above Hankow to be about 11 of the whole area, and assuming that the portion of the Yang-tse valley below Hankow drains off its waters at the same rate as the remainder of the riverbasin, it follows that the average water-discharge for the whole river may be placed at 770,000 cubic feet per second.

With reference to the amount of sediment carried by the Yang-tse past the same city, I found as much as seven grains in the pint (nearly one drachm in the gallon) in the month of July, when the river was at its height; while in March, when the river was low, I found as little as three-fifths of a grain per pint. The average proportion of sediment during the twelve months in question I estimate at four grains in the pint (a little over half a drachm per gallon). This represents a proportion of $\frac{1}{2188}$ by "weight," or (taking the specific gravity of the dried mud at 1 .9) of ${ }^{1}$ " by "bulk" of the average discharge of water. It is thus easy to obtain the total amount of sediment carried during the twelve months past Hankow, namely, $4,945,280,250$ cubic feet : but to allow for the amount of mud a river pushes along its bed, one-tenth must be added according to the principle laid down by Messrs. Humnhreys and Abbot in the case of the Mississippi. This will bring the total anmual discharge of sediment at Hankow up to 5,439,808,275 cubic feet, or at the rate of 172 cubic feet per second. Now, assuming that the drainage area below Hankow sup× "Five Months on the Yang-tse." 
plies the same relative amount of sediment as the remainder of the catchment basin, I estimate the total amount carried down to the sea annually at $6,428,858,255$ cubic feet.

The removal of this amount of sediment from an area of drainage of 650,000 square miles represents a lowering of the surface at the rate of one foot (of rock) in 3,707 years. This is therefore the rate of "subaërial denudation " of the valley of the Yang-tse as far as concerns the quantity of sediment removed. Of the proportion of solids in solution, I have had no opportunity of judging, but that the soluble matter is in considerable quantity is rendered probable from the extensive limestone districts traversed by this river.

2. The Yellow River or the Hoang-ho has derived the appellation of "China's Sorrow" from its frequent destructive inundations. It runs a course of about 2,500 miles; but, unlike the Yang-tse, its lower course has frequently shifted in the course of ages, and although it opens at the present day into the Gulf of Pe-chili, only a quarter of a century has passed since it emptied its waters into the Yellow Sea. ${ }^{2}$ The mountainous district of the province of Shantung has in truth been the chief means in deflecting the waters of this great river on more than one occasion during the historical era from the Gulf of Pe-chili to the Yellow Sea, and vice versá.

With reference to the quantity of water discharged by the Hoang-ho I have had no opportunity of personal observation. We have, however, an estimate not only of the water-discharge, but also of the sediment, which Sir George Staunton supplies us in his account of Lord Macartney's embassy to China in I792. It was calculated that at the place where the British embassy crossed the Yellow River-its junction with the Grand Canal-the water was carried past at the rate of $418,176,000$ cubic feet per hour, or $I I 6,000$ cubic feet per second. The method employed in ascertaining the quantity of sediment was the measurement of the amount of mud deposited from a gallon and three-quarters of water when allowed to stand. From this experiment it was concluded that the sediment was in the proportion of $\frac{1}{2} \delta$ of the original bulk of the water, and the annual discharge of sediment was assessed at $17,520,000,000$ cubic feet.

However carefully these observations may have been made, and however near they may approach the actual discharge of water and of sediment at the time in question, it seems to me that one is hardly justified in accepting the result of a single observation as typical of the average state of things throughout the year; and yet Sir George Staunton's estimate has never, as far as I am aware of, been questioned. A single glance at the foregoing table will convince one of the little dependence that can be placed on a solitary estimation; it will be there seen that the Yang-tse discharged nine times as much water when at its highest level in August as it did cluring the month of January, when its waters occupied their lowest level. ${ }^{2}$ Or if the question of sediment is considered, to which the same objection would apply, I have the greatest diffidence in accepting Sir George Staunton's estimate as being of any value except as a trustworthy result of a single experiment; and yet, even considered as the maximum of the whole year, the result is a rather startling one. While the greatest amount of sediment I found in the water of the Yang-tse was seven grains in the pint, and in the case of the Pei-ho-as will subsequently be noticed-fifteen grains in the pint, Sir George Staunton estimates the sediment of the Yellow River at over eighty grains in the same measure of water. Even the muddy waters of the Ganges do not contain more than twenty grains of sediment in the pint of water.

It is therefore not with any surprise that I find the "subaërial denudation" of the Hoang-ho is estimated ${ }^{3}$ at x Vide Mr. Mossman's paper, already referred to.

2 In the case of the Ganges at Ghazepoor the proportion is as I to I4.

3 Vide NATURE, vol, xviii. p. 268 . less than half that of the Yang-tse, namely, one foot in 1,464 years. This estimate only refers to the amount of sediment removed, and yet I cannot but consider it as very liable to correction by some future observer. As this is the only calculation that has ever been made, as far as I am aware, with reference to the quantities of sediment and of water discharged by the Yellow River, I am perforce obliged to accept it pro tanto.

3. The Pei-ho drains the great plain which constitutes the province of Pe-chili. Its length is said to be about 300 miles, but the lower part of its course below the city of Tientsin is so tortuous that a distance of thirty miles overland is converted into fifty by the river. It is at Tientsin that the Pei-ho proper and the Yu-ho unite together to form the main stream : the latter is generally known by Europeans as the Grand Canal, but as a matter of fact the canal joins the Yu-ho about I 50 miles to the southward. During the three winter months-December, January, and February - the Pei-ho is usually frozen over, the ice having a thickness of about eighteen inches; in the same season there is generally a large quantity of ice in the Gulf of Pe-chili, which may"completely fill up the head of the gulf.

With reference to the water-discharge of this river, I was enabled while wintering at Tientsin during the season I 878-79, to collect some "data" for its estimation during the four months from December to March. Although my estimate strictly applies to but a third of the year, still from the limited rise and fall of the water during the different seasons (it never exceeds six feet) I feel pretty confident that it fairly represents the average rate of discharge during the whole year. The breadth of the river at the place of observation below the city of Tientsin was 280 feet. The following table contains the results of my calculations :-

$$
\begin{aligned}
& \text { 1878. Surface Average Water-discharge. } \\
& \text { Knots per hour. Feet. }
\end{aligned}
$$



$$
\begin{aligned}
& \begin{array}{cccccccccc}
\text { r879. } & & & & & & & & & \\
5 & \ldots & \ldots & 14 & 1 & \ldots & \ldots & 4,389
\end{array} \\
& \begin{array}{lllrllllll}
\text { January } & \ldots & \ldots & \frac{4}{5} & \ldots & \ldots & 14 \frac{1}{2} & \ldots & \ldots & 4,389 \\
\text { February } & \ldots & \ldots & \mathbf{1} \frac{3}{5} & \ldots & \ldots & 16 & \ldots & \ldots & 9,684
\end{array}
\end{aligned}
$$

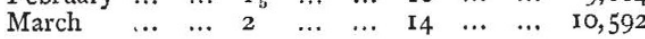

$$
\begin{aligned}
& \text { 4) } 31,020 \\
& 7,755
\end{aligned}
$$

We may thus place the average discharge of water for the whole year at about 7,700 cubic feet per second.

Now with regard to the amount of sediment carried past the city of Tientsin: I found the average quantity during the four months in question to be about five grains per pint. (It varied much at different times, for I found as much as fifteen grains in the middle of March, while in the months of January and February it did not equal a grain in the pint.) This represents a proportion of '1 by "weight," or $\frac{1}{3325}$ by "bulk" of the average discharge of water: and following the same method of calculation as was employed in the case of the Yang-tse, I estimate the annual discharge of sediment for this river at $80,000,000$ cubic feet.

Now the removal of this bulk of material from an area of drainage, which I estimate at 55,000 square miles, represents a lowering of the surface of one foot in 25,218 years. This is the rate of "subaërial denudation" of the Pei-ho basin, omitting of course the question of the solids in solution.

To show the rank that these three rivers hold in the fluvial system of the globe, I have subjoined a list of fourteen other rivers, which gives the quantities of water and sediment discharged by each, as well as the rate of subaërial denudation, as far as I have been able to ascertain. 


\begin{tabular}{|c|c|c|c|c|}
\hline & & $\begin{array}{c}\text { Water discharged } \\
\text { per second. }\end{array}$ & $\begin{array}{l}\text { Sediment per } \\
\text { annum. }\end{array}$ & $\begin{array}{l}\text { Subaërial denuda- } \\
\text { tion. }\end{array}$ \\
\hline. & & & Cubic feet. & $-7+2+$ \\
\hline 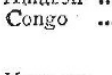 & ... & $\begin{aligned} r, 800 \\
\text { ry B } \\
\text { Capt. }\end{aligned}$ & - & - \\
\hline Yang-tse .. & $\ldots$ & $\left(\mathrm{BY}^{77 \mathrm{C}}\right.$ & $\begin{array}{l}6,428,80 \\
(\text { By my }\end{array}$ & $x$ foot in 3,707 \\
\hline Plate & $\ldots$ & $\begin{array}{c}700,030 \\
\text { (By Mr. Higgin } \\
\text { and Mr. Bateman) }\end{array}$ & $\begin{array}{c}\text { r,543,500,000 } \\
\text { (By Mr. Higgin) }\end{array}$ & $\begin{array}{c}\text { I foot in } 29,400 \\
\text { years. } \\
\text { (Calculated from } \\
\text { Mr. Higgin's } \\
\text { estimate) }\end{array}$ \\
\hline Mississippi & $\ldots$ & $\begin{array}{c}\text { 6r8,ooo } \\
\text { (Byy Messrs. IIum- }\end{array}$ & $\begin{array}{l}7,474,000,000 \\
\text { (Ey Messrs. Hum- Hum- }\end{array}$ & $\begin{array}{c}\text { estimate) } \\
x \text { foot in 6,ooo } \\
\text { ycars. } \\
\text { (By Mr. Croll) }\end{array}$ \\
\hline Danube .. & $\ldots$ & $y=$ & $\begin{array}{l}\text { r,255,500,00 } \\
\text { (By Mr. Ch. } \\
\text { Hartley) }\end{array}$ & $\begin{array}{c}\text { Ifoot in } 6,846 \\
\text { years. }\end{array}$ \\
\hline Shat-el-Ara & b... & & & - \\
\hline $\begin{array}{l}\text { Ganges, } \\
\text { Ghazepos }\end{array}$ & at & $\begin{array}{l}203,85 \\
\text { (By the Kev. Mr. } \\
\text { Liverest) }\end{array}$ & $\begin{array}{c}\text { 6,368,000,000 } \\
\text { (By tlis Rev. Mr. } \\
\text { Everest) }\end{array}$ & $\begin{array}{c}\text { If foot in } 2,358 \\
\text { years. }\end{array}$ \\
\hline $\begin{array}{l}\text { Indus } \\
\text { Atrato }\end{array}$ & $\ldots$ & & $=$ & $=$ \\
\hline$\ddot{v}$ Riv & $\cdots$ & $\begin{array}{c}\text { 130,032 } \\
116,000 \\
\text { (By Sir George }\end{array}$ & $\begin{array}{l}-{ }^{17,520,000,000} \\
\text { (By Sir George }\end{array}$ & 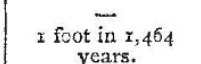 \\
\hline Rlione . & $\cdots$ & $\begin{array}{l}\text { Staunton) } \\
9 x, 935\end{array}$ & $\begin{array}{l}\text { Staunton) } \\
594,000,000\end{array}$ & $x$ foot in $x, 528$ \\
\hline $\begin{array}{l}\text { Rhine } \\
\text { Po ... .. }\end{array}$ & $\ldots$ & $\begin{array}{l}69, \\
6 r,\end{array}$ & $\begin{array}{c}- \\
405,420,000 \\
\text { (By M. Lom- }\end{array}$ & $r$ foot in 729 years. \\
\hline Pei-ho & $\ldots$ & (By myself) & $\begin{array}{l}\text { 8o, } \\
\text { (By }\end{array}$ & 5,228 \\
\hline $\begin{array}{l}\text { Thames, } \\
\text { Kningston }\end{array}$ & at & $\begin{array}{l}\text { (By Prof Prest- } \\
\text { wich) }\end{array}$ & $\begin{array}{c}\text { 1,865,900 } \\
\text { (Huxley's } \\
\text { "Thysiograylyy.") }\end{array}$ & $\begin{array}{c}\text { x foot in } 9,600 \\
\text { years, } \\
\text { (Huxley's } \\
\text { "Physiography.") }\end{array}$ \\
\hline
\end{tabular}

We have now the necessary "data" for considering these three rivers in their conjoint character. Together they drain an area of $\mathrm{I}, 105,000$ square miles; they discharge a body of water equal to 894,000 cubic feet every second; and they carry down every year to the sea $24,028,800,000$ cubic fect of sediment, which represents a rate of subaerial denudation equal to the removal of one foot of solid rock in 1,687 years.

If we look upon the Yang-tse, the Yellow River, and the Pei-ho as labouring, with the assistance of the gradual elevation of the sea-border which is at present going on, to extend the territory of China seaward towards her ancient coast-line-represented by a line running from Kamtschatka through the Kurile Islands, Japan, the Loo-choo group, Formosa down to the Malay Archipelago ${ }^{4}$ and carry ourselves forward into the future when such task is completed and the waves of the Pacific beat once more against this old sea-border, we shall not have much difficulty in picturing to ourselves what will then be the state of matters. In the place of the gulf of Pe-chili and the Yellow Sea there will be vast alluvial plains traversed by the waters of the Yang-tse, the Yellow River, and the Fei-ho; but before the ancient coast-line is reached they will have joined to form one great river and one united delta. If the Ycllow River confines itself mostly in future ages to its course in to the gulf of Pe-chili, that gulf will be filled up in process of time; and the Hoang ho winding along through the bed of this obliterated sea will, after being joined by the Pei-ho, turn its course southward, deflected by the Corcan peninsula, until it meets at length its sister stream. On the other hand, should the Yellow River be mostly occupied in future in advancing its southern delta it will join the Yang-tse at a period much less remote from the present; and their

I Where not otherwise mentioned I have obtained my information of the discharge of water and sediment from the "Earth," by Elisée Reclus.

2 This estimate also includes the solids held in solution.

3 In Page's "Advanced Text-book of Ceology" Staunton's estimate of the sediment discharged by the Yellow River has been erroncously applied to all "the great Chinese rivers."

$4 \mathrm{Vidc}$ a paper on this subject, by Mr. A. S. Bickmore, read before the Nortla China branch of the Astatic Society in November, 1867 . united waters will pursue an easterly direction subsequently to be joined by the Pei-ho, which will have been gradually finding its way through the gulf of $\mathrm{Pe}$-chili and the Yellow Sea during the preceding ages. In either event the union of these three rivers would follow.

Such being the case, it may be interesting to speculate on the time required by these rivers to fill up the seas into which they discharge their sediment. Sir George Staunton estimated that at the rate the Hoang-ho was discharging sediment it would fill up the Yellow Sea and the gulfs of Pe-chili and Lian Tung in 24,000 years; but M. Elisée Reclus is of opinion that this estimate ought to be doubled, as the Ycllow Sea is much deeper than Sir George Staunton stated it to bc ( 20 fathoms). On carefully examining the latest charts of these seas I am inclined to consider that this estimate cannot be assailed on this point, as my own detcrmination of the average depth is 22 fathoms.

We will now attempt to gauge the time that the three rivers in question would require to fill up by the sediment they deposit the portion of sea which is included by the gulfs of Pe-chili and Lian Tung, the Yellow Sea, and the Eastern Sea north of the 29th parallel and west of the I26th meridian. I have placed the total surface area at 200,000 English square miles, and the average depth at 26 fathoms; and following Sir George Staunton's mode of estimation I find that it would take sixty-six days to form an island a mile square reaching up to the surface of the sea. $\Lambda t$ this rate it would require 36,000 years to form all the sea in question into dry land, supposing of course that there was no elevation or depression of the sea-bottom during that period. But, the recent formation of several islands and shoals in the Yang-tse estuary, the occurrence of raised beaches and marine remains at Hang-chau, Wusung, and Chefoo, with other similar evidences, demonstrate that there is an elevation of the coast going on at present; and, in that case, it will require considerably less than 36,000 years to form the sea into terra fima. Perhaps Sir George Staunton's original estimate for the Yellow River may not be far wrong when applied to the whole sea in question.

\section{PHYSICS WITHOUT APPARATUS ${ }^{1}$}

\section{VI}

$A$ COUSTICAL expertments require, for the most part, the aid of some good instrument or valuable piece of apparatus. Neverthcless a few instructive illustrations of the principles of the science can be improvised without difficulty. Firstly, there is the familiar experiment brought into fashion, we believe, by Prof. Tyndall, of setting a row of ivory billiard balls or glass solitaire marbles along a groorc between two wooden boards, and showing how their elasticity enables them to transmit from one to another a wave of moving energy imparted to the first of the row, thus affording a type of the transmission of sound-waves from particle to particle through elastic media. Then we may show how sounds travel through solid bodies by resting against a music box or other musical instrument, a broomstick, or any convenient rod of wood, at the other end of which we place our ear. A kindred experiment, illustrative of the transmission of sounds through threads, is depicted in Fig. 20. A large spoon is ticd to the middle of a thin silken or hempen thread, the ends of which are thrust into the ears upon the ends of the thumbs. If the spoon be dangled against the edge of the table it will resound, and the tones reach the ear like a loud church bell. The thread telephone or "lover's telegraph," is upon the same principle, the thread transmitting the whispered words to a distance, without that loss by spreading in all directions which takes place in the open air. 